\title{
HUBUNGAN POLA HIDUP DAN BERAT BADAN MAHASISWA PENDIDIKAN BIOLOGI SEMESTER 7A
}

\author{
Anisa Nurul Auliah ${ }^{1}$, Annisa Latifah Nur'aeni², Elma Nur Hidayati ${ }^{3}$, \\ Iwan Ridwan Yusup ${ }^{4}$ \\ ${ }^{1,2}$ Universitas Islam Negeri Sunan Gunung Djati Bandung \\ e-mail : 19anisaauliah26@gmail.com, 2latifahannisa2@gmail.com, \\ 3elmanh74@gmail.com, 4iwanyusup@uinsgd.ac.id
}

\begin{abstract}
ABSTRAK
Kualitas pola hidup mempengaruhi indikasi dari berat badan. Mahasiswa sebagai akademisi dituntut untuk memiliki kualitas hidup yang sehat..Tujuan dari penelitian ini untuk mengetahui pengaruh pola hidup terhadap berat badan mahasiswa pendidikan biologi kelas 7A. Metode yang digunakan bersifat survey analitik dengan study cross sectional. Pengambilan sampel dilakukan dengan menggunakan teknik sampling kuota yaitu semua mahasiswa Pendidikan Biologi semester 7 kelas A UIN Sunan Gunung Djati Bandung sebanyak 37 orang. Hasil dari penelitian ini mahasiswa rata-rata memiliki pola hidup yang sama, kecuali pada faktor genetik. Maka simpulan yang didapatkan faktor yang paling berpengaruh pada kondisi berat badan adalah faktor genetic dengan persentase ibu yang ideal 50\% dan ayah yang ideal 57,7 \%.
\end{abstract}

Kata kunci : Berat Badan, Pola Hidup, Mahasiswa

\begin{abstract}
Quality of life patterns influences the indication of body weight. Students as academics are required to have a healthy quality of life. The purpose of this study is to determine the effect of lifestyle on the weight of 7A grade biology education students. The method used is analytical survey with cross sectional study. Sampling was carried out using quota sampling techniques, namely all Biology Education students in the 7th grade of AIN Sunan Gunung Djati Bandung as many as 37 people. The results of this study on average students have the same lifestyle, except for genetic factors. So the conclusion that the most influential factor influencing weight condition is genetic factor with the percentage of ideal mothers $50 \%$ and ideal father $57.7 \%$.
\end{abstract}

Keywords: Weight, Lifestyle, Students 


\section{PENDAHULUAN}

Saat ini di Indonesia muncul masalah gizi yang dikenal dengan masalah gizi ganda (double burden). Di satu sisi masalah kurang gizi masih banyak namun disisi lain masalah gizi terus meningkat, hal ini terjadi disemua kelompok usia dimulai dari pedesaan sampai ke perkotaan. Kurang gizi dapat meningkatkan risiko terhadap penyakit infeksi dan gizi lebih, dengan akumulasi yang berlebih dapat meningkatkan risiko menderita penyakit degenerative. Selain itu kurang gizi menimbulkan masalah pada berat badan (Depkes RI, 2010).

Berat badan merupakan salah satu parameter yang penting untuk mengetahui kondisi tubuh seseorang. Melalui berat badan dapat diketahui berbagai informasi untuk menganalisa kondisi tubuh seseorang. Menurut World Health Organitation (WHO 2010) faktor resiko penyebab kematian ke-5 di dunia yaitu kelebihan berat badan (Overweight) dan kegemukan (Obesity). Setidaknya ada 2.8 juta penduduk di dunia meninggal akibat komplikasi obesitas, 23\% menderita penyakit jantung iskemik, dan $7 \%$ sampa $41 \%$ mempunyai resiko terkena kanker pada organ tertentu. Menurut (Supariasa, 2013) dalam Nugroho (2016) Dengan IMT dapat memantau status gizi seseorang yang berhubungan dengan kelebihan dan kekurangan berat.

Aktivitas fisik merupakan salah satu faktor yang mempengaruhi status gizi. Asupan energi yang berlebih dan tidak diimbangi dengan pengeluaran energi yang seimbang (dengan kurang melakukan aktivitas fisik) akan dengan mudah menambah berat badan. Terjadinya perubahan pola makan disebabkan karena adanya perubahan gaya hidup masyarakat yang memilih pada pola makan tinggi kalori, lemak dan kolestrol, dengan tidak diimbanginya aktivitas fisik yang akan menyebabkan gizi lebih. Apabila terjadi ketidakseimbangan energi akan mengarah pada kelebihan berat badan. (Ayu, 2011).

Pola makan dapat diartikan suatu kebiasaan menetap dalam hubungan dengan konsumsi makan yaitu berdasarkan jenis bahan makanan yaitu makanan pokok, sumber protein, sayuran, buah-buahan, dan berdasarkan pada frekuensi harian, mingguan, pernah, dan tidak pernah sama sekali. Dalam hal pemilihan makanan dan waktu makan, biasanya dipengaruhi oleh selera pribadi, usia, kebiasaan, dan sosial ekonomi (Almatsier. 2002). Menurut (Ginting, 2002) Pola makan yang dapat diamati meliputi frekuensi makan, waktu makan dan tingkat konsumsi.

Selain aktivitas fisik dan pola makan, durasi tidur menjadi salah satu faktor dalam berat badan dan metabolisme. Dua hormon yang sangat memainkan peranan dalam interaksi antara durasi tidur yang pendek dengan tingginya IMT yaitu hormon leptin dan hormon ghrelin. Pola tidur yang singkat sangat berpengaruh terhadap pola makan karena peningkatan grehlin dan penurunan resistensi leptin (Relda, 2013).

Banyak faktor yang turut berperan sehingga pola tidur berubah, seperti pergesaran ke era teknologi maju, era informasi, internet, game di berbagai negara termasuk di Indonesia turut berperan dalam hal ini.

Beberapa penelitian telah dilakukan mengenai hubungan pola makan, pola tidur dan aktivitas fisik dengan berat badan. Penelitian yang dilakukan oleh Relda dkk (2013) terdapat hubungan antara durasi waktu tidur dengan kelebihan berat badan. 
Kemudian penelitian yang dilakukan oleh Dewi (2016) terdapat hubungan antara pola makan dengan indeks massa tubuh (IMT). Hal ini tampak menggambarkan bahwa pola tidur atau durasi waktu tidur yang tidak baik, dan pola makan yang tidak baik merupakan salah satu faktor penyebab adalah salah satu faktor penyebab berat badan lebih dan berat badan kurang.

\section{METODE}

Penelitian ini bersifat survey analitik dengan study cross sectional. Penelitian ini dilaksanakan di kampus UIN Sunan Gunung Djati Bandung dan dilakukan pada bulan Okteober 2019. Pengambilan sampel dilakukan dengan menggunakan teknik sampling kuota yaitu semua mahasiswa Pendidikan Biologi semester 7 kelas A UIN Sunan Gunung Djati Bandung sebanyak 37 orang.
Data yang terkumpul berupa kuesioner dioalah dengan menggunakan program computer kemudian disajikan dalam bentuk tabel distribusi disertai dengan penjelasan dan diagram distribusi.

Pengolahan data status berat badan mahasiswa, ditentukan dengan menggunakan Indeks Massa Tubuh dengan menggunakan rumus sebagai berikut:

\section{Berat badan $(\mathrm{kg})$ \\ $\overline{\text { Tinggi badan }(\mathrm{m}) x \text { tinggi badan }(\mathrm{m})}$}

kemudian dibandingkan dengan kategori berat badan sebagai berikut:

Kurus

$<\mathbf{1 8 . 5}$

$<18.5$

Normal

18.5-24.9

$18.5-22.9$

Overweight

$25-29.9$

$23-24.9$

Obesitas

$\geq 25$

\section{HASIL DAN PEMBAHASAN}

Tabel 1. Distribusi Frekuensi Pola Makan,Keturunan, Rutinitas Berolahraga, Pola Tidur, Penggunaan Media dan Status Badan

\begin{tabular}{lcc}
\hline \multicolumn{1}{c}{ Variabel } & n & Presentase (\%) \\
\hline Pola Makan & & \\
Jam Makan & 4 & $11,5 \%$ \\
Teratur & 33 & $88,5 \%$ \\
Tidak Teratur & & \\
\hline & & \\
Asupan Serat & 3 & $7,7 \%$ \\
Sayur dan buah & 28 & $76,9 \%$ \\
Makanan Berminyak & 6 & $15,4 \%$ \\
Seimbang & & \\
Keturunan & & \\
Ibu & 10 & $26,9 \%$ \\
Gemuk & 9 & $23,1 \%$ \\
Kurus & 18 & $50 \%$ \\
Ideal & & \\
Ayah & 9 & $23,1 \%$ \\
Gemuk & 7 & $19,2 \%$ \\
Kurus & 21 & $57,7 \%$ \\
Ideal & &
\end{tabular}




\begin{tabular}{lcc}
\hline Rutinitas Berolahraga & & \\
Rutin & 4 & $11,5 \%$ \\
Tidak Rutin & 33 & $88,5 \%$ \\
Pola Tidur & & \\
Teratur & 1 & $3,8 \%$ \\
Tidak Teratur & 36 & $96,2 \%$ \\
\hline Status Berat Badan & & \\
Gemuk & 2 & $5,4 \%$ \\
Kurus & 4 & $10,8 \%$ \\
Ideal & 31 & $83,8 \%$ \\
\hline
\end{tabular}

Tabel 1. Menunjukkan bahwa dari 37 mahasiswa terdapat pola makan dengan jam makan yang teratur sebanyak 11, 5\% sedangkan tidak teratur sebanyak $88,5 \%$. Dari 37 mahasiswa terdapat pola makan dengan jenis makan sayur dan buah sebanyak 7,7\%, jenis makanan berminyak sebanyak 76,9\% sedangkan yang memiliki pola makan dengan jenis makanan seimbang sebanyak 15,4\%. Pada faktor keturunan menunjukkan dari 37 mahasiswa terdapat keturunan ibu yang gemuk sebanyak 26,9\%, ibu yang kurus sebanyak 23,1\% sedangkan ibu yang ideal sebanyak 50\%. Keturunan dari bapak yang gemuk sebanyak 23,1\%, bapak yang kurus 19,2\% sedangkan bapak yang ideal sebanyak 57,7\%. Rutinitas berolahraga menunjukkan dari 37 mahasiswa terdapat rutin berolahraga sebanyak $11,5 \%$ sedangkan yang tidak rutin berolahraga sebanyak 88,5\%. Pola tidur menunjukkan 37 mahasiswa terdapat pola tidur yang teratur sebanyak 3,8\% sedangkan yang tidak teratur sebanyak 96,2\%. Penggunaan media menunjukkan 37 mahasiswa terdapat penggunaan media selama $<5$ jam dalam sehari sebanyak15,4\% sedangkan penggunaan media selama $>5$ jam dalam sehari sebanyak 84,6\%. Status berat badan menunjukkan dari 37 mahasiswa terdapat status gemuk sebanyak $5,4 \%$, status kurus sebanyak 10,8\% sedangkan status ideal sebanyak $83,8 \%$.

\section{Pola Makan}

Kebanyakan mahasiswa sering melewatkan sarapan pagi karena terbatasnya waktu pada saat pagi, mereka memilih tidak sarapan karena apabila mereka sarapan terlebih dahulu akan terlambat masuk kelas sehingga mereka biasanya makan pada saat istirahat siang hari.

Melewatkan sarapan akan mengakibatkan merasa sangat lapar dan tidak dapat mengontrol nafsu makan sehingga pada saat makan siang akan makan dalam porsi yang berlebih (overreacting). Saat kita melewatkan sarapan, kita cenderung untuk makan berlebihan saat makan sang. Padahal saat melewatkan makan, metabolisme tubuh melambat dan tidak mampu membakar kalori berlebihan yang masuk saat makan siang tersebut. Hal ini sesuai dengan penelitian yang dilakukan di Amerika Serikat bahwa anak atau remaja yang meninggalkan sarapan akan berisiko untuk menjadi overweight atau obesitas dibandingkan mereka yang sarapan (Rampersaud, dkk: 2005).

\section{Faktor gen}

Faktor genetik berhubungan dengan pertambahan berat badan, IMT, lingkar pinggang, dan aktivitas fisik. Jika ayah dan atau ibu menderita kelebihan berat badan maka kemungkinan anaknya memiliki kelebihan berat badan sebesar 40-50\%. 
Apabila kedua orang tua menderita obesitas kemungkinan anaknya menjadi obesitas sebesar 70-80\% .

Faktor genetik sangat berperan dalam peningkatan berat badan. Data dari berbagai studi genetik menunjukkan adanya beberapa alel yang menunjukkan predisposisi untuk menimbulkan obesitas. Di samping itu, terdapat interaksi antara faktor genetik dengan kelebihan asupan makanan padat dan penurunan aktivitas fisik. Studi genetik terbaru telah mengidentifikasi adanya mutasi gen yang mendasari obesitas. Terdapat sejumlah besar gen pada manusia yang diyakini mempengaruhi berat badan dan adipositas.

Berdasarkan penelitian diketahui bahwa orang tua mempengaruhi pola makan anak dan gaya hidup yang sama dalam keluarga. Keluarga mewariskan kebiasaan pola makan dan gaya hidup yang sama, sehingga hubungan antara gen dan lingkungan saling mendukunng. Cukup alami bila anak-anak mengadopsi kebiasaan orang tua mereka. Seorang anak yang orang tuanya gemuk yang terbiasa makan makanan berkalori tinggi dan tidak aktif, kemungkinan besar anak tersebut akan mewarisi kebiasaan serupa dan menjadikannya kelebihan berat badan juga (Rina, 2012).

\section{Asupan Serat}

Berdasarkan hasil pengamatan mahasiswa dominan memilih makanan berminyak daripada sayur dan buah. Banyak alasan yang menyebabkan mahasiswa pada penelitian ini jarang mengkonsumsi sayuran dan buah-buahan, salah satunya karena kurang suka dengan sayur dan tidak ada waktu di rumah untuk makan sayur dan buah akibat aktivitas yang lebih banyak di luar rumah. Beberapa mahasiswa mengaku bahwa. lebih suka mengkonsumsi jenis makanan kering seperti gorengan, aneka lauk (ayam, ikan, daging, dll), aneka jajanan (batagor, sosis goreng, bakso, mi ayam), dan makanan manis seperti roti dan kue. Jenis makanan yang dikonsumsi tersebut sedikit mengandung serat.

Pola makan dan kebiasan makan pada subjek penelitian cenderung ke arah makanan yang berlemak, berminyak serta mengandung banyak pati dan gula sehingga hal tersebut akan menyebabkan asupan serat menjadi rendah. Selain itu, tersedianya kantin, restauran cepat saji, dan pedagang keliling di sekitar area kampus yang umumnya menyajikan makanan yang berlemak dan berminyak juga mempengaruhi asupan serat pada mahasiswa. Pola konsumsi yang diterapkan remaja sekarang ini adalah makanan yang tinggi energi namun sedikit mengandung serat (Rahayuningtyas,2012)

\section{Rutinitas Berolahraga}

Untuk memiliki tubuh yang sehat dan ideal pada mahasiswa perlu dilakukan aktivitas fisik yang sesuai, aman dan efektif dalam upaya menurunkan berat badan. Seperti dengan berolahraga teratur dan terkontrol, karena akan membantu memelihara berat badan yang optimal, karena gerak yang dilakukan saat berolahraga sangat berbeda dengan gerak saat menjalankan aktivitas sehari-hari seperti berdiri, duduk atau hanya menggunakan tangan.

Olahraga yang dilakukan dengan tepat, teratur, dan terukur dapat memberikan peningkatan pengeluaran energi yang cukup besar untuk menjaga atau menurunkan berat badan secara berkala. Selain itu olahraga yang teratur dapat menjaga dan 
meningkatkan daya tahan tubuh atau kebugaran jasmani dan menghindarkan atau meminimalisasi dari berbagai scrangan penyakit.

\section{Pola Tidur}

Beberapa penelitian longitudinal menunjukkan temuan yang bervariasi mengenai hubungan kuantitas dan kualitas tidur terhadap peningkatan berat badan. Seperti yang digarisbawahi oleh Aylin dkk (2014), subjek yang kurang tidur mengalami peningkatan berat badan yang diakibatkan oleh beberapa faktor seperti kurangnya aktifitas fisik akibat rasa kantuk disiang hari dan peningkatan nafsu makan, dan subjek yang memiliki berat badan lebih tinggi akan mengalami kekurangan tidur akibat masalah kesehatannya atau akibat terganggunya kualitas tidur.

Ketika tidur malam, tubuh yang sudah bekerja keras selama seharian penuh akan menjadi lebih rileks. Ketika tubuh rileks dan metabolisme tubuh berjalan normal, tubuh akan lebih mudah mencerna makanan dan tidak akan merasa lapar terus menerus.

\section{SIMPULAN DAN SARAN}

Faktor yang paling berpengaruh pada kondisi berat badan adalah faktor genetik, karena rata-rata mahasiswa memiliki pola hidup yang sama. Namun, belum tentu setiap mahasiswa memiliki badan yang sehat karena pola hidup yang tidak teratur, maka dari itu disarankan agar mahasiswa lebih memperhatikan pola hidup sehat dengan asupan gizi yang seimbang.

\section{DAFTAR PUSTAKA}

Almatsier, S, 2009. Prinsip Dasar Ilmu Gizi. Jakarta: Gramedia Pustaka Utama

Departemen Kesehatan RI, 2010. Profil
Kesehatan Indonesia. Jakarta : Depkes RI

Ginting, N, 2002. Hubungan Pengetahuan Gizi Dengan Pola Makan Pada Mahasiswa Kesehatan dan Non Kesehatan Yang Kos Di Kelurahan Padang ulan Kecamatan Medan Baru. Universitas Sumatera Utara.

Nurmalina Rina, 2001. Pencegahan dan Manajemen Obesitas. Bandung: Elex Media Komputindo.

Rahayuningtyas F, 2012. Hubungan antara asupan serat dan faktor lainnya dengan status gizi lebih pada siswa SMPN 115 Jakarta Selatan Tahun 2012 [Skripsi]. Jakarta: Fakultas Kesehatan Masyarakat, Universitas Indonesia.

Rampersaud GC, Pereira MA, Girard BL, Adams J, Metzl JD, 2005.

Breakfast habits, nutritional status, body weight, and academic performance in children and adolescents. J Am Diet Assoc.

Relda, dkk, 2013. Gambaran Durasi Tidur Pada Remaja dengan Keleihan Berat Badan. Jurnal e-Biomedik (eBM), Volume 1, Nomor 2, Juli 2013, hlm. 849-853.

Supariasa, I.D.N, 2013. .Penilaian Status Gizi. edited by Monica Ester. Jakarta :EGC.

WHO, 2010. Population-based Prevention Strategies for Childhood Obesity.Geneva: WHO 